\title{
ANALISIS NIAT BELI ASURANSI JIWA PADA MAHASISWA: APLIKASI THEORY OF PLANNED BEHAVIOR
}

\author{
Novie Astri Pratiwi ${ }^{1}$, Hartoyo $\left.^{1 *}\right)$ \\ ${ }^{1}$ Departemen IImu Keluarga dan Konsumen, Fakultas Ekologi Manusia, Institut Pertanian Bogor, \\ Bogor 16680, Indonesia \\ *E-mail: hartoyo@ipb.ac.id
}

\begin{abstract}
Abstrak
Pengambilan keputusan dalam membeli produk asuransi jiwa dapat dibentuk oleh sikap yang mendukung terbentuknya niat membeli produk tersebut. Tujuan penelitian ini adalah menganalisis niat beli asuransi jiwa pada mahasiswa menggunakan aplikasi teori tentang perilaku yang direncanakan (Theory of Planned Behavior). Penelitian ini menggunakan desain cross sectional dan melibatkan 250 mahasiswa yang mengikuti mata kuliah Manajemen Keuangan Konsumen (MKK). Karakteristik mahasiswa diukur dalam tiga dimensi, yaitu karakteristik sosial demografi, nilai yang dianut, dan pengetahuan keuangan. Hasil penelitian menunjukkan bahwa proporsi terbanyak mahasiswa memiliki nilai harga diri pada kategori tinggi namun memiliki nilai keamanan pada kategori rendah. Pengetahuan keuangan, baik pengetahuan keuangan subjektif maupun objektif, sikap terhadap asuransi jiwa, norma subjektif, dan kontrol perilaku yang dirasakan oleh mahasiswa terbilang cukup baik. Hasil analisis menunjukkan bahwa niat beli asuransi jiwa berhubungan positif signifikan dengan sikap terhadap asuransi jiwa $(r=0,634 ; p<0,01)$, norma subjektif $(r=0,470 ; p<0,01)$, dan kontrol perilaku yang dirasakan $(r=0,508 ; p<0,01)$. Niat beli asuransi jiwa dipengaruhi oleh nilai keamanan dan harga diri, pengetahuan keuangan subjektif, serta sikap terhadap asuransi jiwa.
\end{abstract}

Kata kunci: asuransi jiwa, niat beli, nilai, pengetahuan keuangan, perilaku yang direncanakan

\section{Analysis Life Insurance Purchase Intention of College Students: The Application of the Theory of Planned Behavior}

\begin{abstract}
The decision making to buy the life insurance product can be determined by supported attitude for the intention. The purpose of this research was to analyze life insurance purchase intention of college students using the application of the Theory of Planned Behavior (TPB). This research used cross sectional design and involved 250 college students who attended Personal Financial Management Course. Characteristics of college students were measured among three dimensions that were social demography characteristics, value, and financial knowledge. The results indicated that the most of students had high self-respect value score but low security value score. The level of financial knowledge, both subjective and objective measurement of knowledge, attitude toward life insurance product, subjective norms, and perceived behavioral control were considered to be at good level. Further analysis indicates that life insurance purchase intention was significantly correlated with attitudes toward life insurance product $(r=0,634 ; p<0,01)$, subjective norm $(r=0,470 ; p<0,01)$, and perceived behavioral control $(r=0,508 ; p<0,01)$. Life insurance purchase intention is influenced by the value of security and self-respect, subjective financial knowledge, and attitude toward life insurance product.
\end{abstract}

Keywords: financial knowledge, life insurance, planned behavior, purchase intention, value

\section{PENDAHULUAN}

Perencanaan keuangan pribadi sangat dibutuhkan oleh setiap individu. Perencanaan keuangan perlu dilakukan untuk mencapai tujuan keuangan seseorang (Hallman \& Rosenbloom, 2003). Perencanaan keuangan dibutuhkan karena individu selalu dihadapkan ketidakpastian mengenai kemungkinan yang akan terjadi dalam hidupnya, salah satu bentuknya adalah asuransi.
Asuransi merupakan alat transfer risiko yang sangat penting (Hallman \& Rosenbloom, 2003). Meskipun asuransi memiliki kedudukan yang penting untuk mengatasi ketidakpastian namun penggunaan asuransi masih tergolong rendah. Data yang terdapat dalam World Insurance in 2010 yang dirilis oleh Swiss $\mathrm{Re}$ (2011) pun menyatakan bahwa Indonesia tergolong negara yang terpuruk dalam upaya pelindungan atau proteksi terhadap jiwa manusia. Indonesia menempati peringkat ke-11 
dari 27 negara di Asia. Merujuk pada fakta tersebut maka niat beli terhadap asuransi jiwa menjadi penting untuk diperhatikan. Namun, mahasiswa memiliki pengetahuan keuangan yang cukup baik, sehingga mahasiswa mengetahui definisi, tujuan, dan manfaat dari perencanan keuangan (Astuti \& Hartoyo, 2013). Mahasiswa sebagai generasi penerus bangsa dan individu yang akan membangun keluarga Indonesia di masa depan diharapkan memiliki perencanaan keuangan yang baik dan mempersiapkan diri dalam menghadapi risiko dengan memiliki niat beli asuransi jiwa.

Menurut Theory of Planned Behavior (TPB) yang dikembangkan oleh Ajzen (1991), niat dibangun dari tiga komponen utama yaitu sikap terhadap perilaku, norma subjektif, dan kontrol perilaku yang dirasakan. Setiap orang perlu menyadari bahwa keyakinan perilaku, keyakinan normatif, dan keyakinan kontrol dipengaruhi oleh berbagai faktor seperti faktor pribadi, budaya, dan situasi (Ajzen \& Fishbein, 2005). Faktor tersebut dikelompokkan menjadi tiga bagian yaitu sosial demografi, individu, dan informasi. Nilai merupakan salah satu bagian individu yang mungkin akan berbeda antara satu orang dengan yang lainnya, begitu pun pengetahuan yang merupakan bagian informasi.

Berdasarkan pemaparan tersebut, penelitian ini bertujuan untuk: (1) mengidentifikasi nilai dan tingkat pengetahuan keuangan yang menjadi dasar dalam niat beli asuransi jiwa, (2) mengidentifikasi sikap terhadap asuransi jiwa, norma subjektif, kontrol perilaku yang dirasakan, serta niat beli asuransi jiwa, (3) menganalisis hubungan nilai dan pengetahuan keuangan dengan sikap terhadap asuransi jiwa, norma subjektif, dan kontrol perilaku yang dirasakan, (4) menganalisis hubungan sikap terhadap asuransi jiwa, norma subjektif, dan kontrol perilaku yang dirasakan dengan niat beli asuransi jiwa, serta (5) menganalisis faktor apa saja yang berpengaruh terhadap niat beli asuransi jiwa.

\section{METODE}

Penelitian ini menggunakan desain cross sectional yaitu penelitian yang dilakukan pada satu waktu. Penelitian dilakukan pada bulan Februari 2012 di Kampus Institut Pertanian Bogor (IPB). Responden dalam penelitian ini adalah mahasiswa yang mengikuti mata kuliah Manajemen Keuangan Konsumen (MKK) pada semester genap tahun ajaran 2011/2012 yang dipilih secara purposive. Berdasarkan total 390 mahasiswa yang terdaftar dalam mata kuliah tersebut, 335 mahasiswa yang hadir pada pertemuan kuliah minggu pertama dan mengisi kuesioner (85,9\%). Namun dari total 335 mahasiswa yang mengisi kuesioner terdapat 85 mahasiswa $(21,8 \%)$ yang harus dikeluarkan dari penelitian karena tidak mengisi kuesioner dengan lengkap sehingga total responden dalam penelitian berjumlah 250 mahasiswa.

Data yang digunakan terdiri atas data primer yang diperoleh dari kuesioner yang diisi sendiri oleh responden. Data tersebut meliputi karakteristik sosial demografi, karakteristik individu, karakteristik informasi, dan variabel dalam model TPB. Karakteristik sosial demografi meliputi jenis kelamin, usia, lama pendidikan, mayor, uang saku, IPK, usia orang tua, lama pendidikan orang tua, pekerjaan orang tua, pendapatan keluarga, dan besar keluarga. Karakteristik individu terdiri atas dimensi nilai keamanan (Cronbach's alpha= 0,657), harga diri (Cronbach's alpha=0,729), pemenuhan diri (Cronbach's alpha $=0,628)$, dan pencapaian prestasi (Cronbach's alpha $=0,708$ ). Karakteristik informasi meliputi pengetahuan keuangan subjektif dan objektif. Sementara variabel dalam model TPB terdiri atas sikap terhadap asuransi jiwa (Cronbach's alpha= 0,894), norma subjektif (Cronbach's alpha= $0,946)$, kontrol perilaku yang dirasakan (Cronbach's alpha=0,862), dan niat beli asuransi jiwa.

Data diolah dengan menggunakan analisis deskriptif, korelasi Pearson, dan regresi logistik. Analisis deskriptif digunakan untuk mengidentifikasi seluruh variabel dalam penelitian. Analisis korelasi Pearson digunakan untuk menganalisis hubungan nilai dan pengetahuan keuangan dengan sikap terhadap asuransi jiwa, norma subjektif, dan kontrol perilaku yang dirasakan serta hubungan antara sikap terhadap asuransi jiwa, norma subjektif, dan kontrol perilaku yang dirasakan, dengan niat beli asuransi jiwa. Sementara itu, analisis regresi logistik digunakan untuk menganalisis faktor-faktor yang berpengaruh pada niat beli asuransi jiwa, dengan variabel dependennya dibedakan menjadi niat membeli (1) dan tidak niat membeli $(0)$.

\section{HASIL}

\section{Karakteristik Sosial Demografi}

Jumlah mahasiswa yang menjadi responden dalam penelitian adalah 250 mahasiswa. Sebagian besar berjenis kelamin perempuan (80,0\%). Responden berusia antara 18 hingga 23 tahun dengan rata-rata usia 
adalah 20 tahun. Sebagian besar usia mahasiswa $(79,2 \%)$ berada pada tahapan dewasa awal (20-40 tahun) sedangkan sisanya $(20,8 \%)$ berada pada tahapan remaja akhir (<20 tahun).

Lama pendidikan merupakan lama mahasiswa berkuliah di IPB yang dihitung berdasarkan jumlah bulan. Sebagian besar lama pendidikan mahasiswa $(75,6 \%)$ adalah 31 bulan dan hanya 4 persen saja lama pendidikan mahasiswa yang sudah mencapai 43 bulan. Artinya sebagian besar mahasiswa berada pada semester 6 , hanya 4 persen mahasiswa yang berada pada semester 8 . Berdasarkan mayor, mahasiswa yang menjadi responden dalam penelitian ini berasal dari seluruh fakultas yang ada di IPB kecuali Fakultas Kedokteran Hewan. Persentase terbesar mayor mahasiswa $(21,6 \%)$ berasal dari Departemen IImu Keluarga dan Konsumen (IKK), Fakultas Ekologi Manusia. Hal ini disebabkan karena MKK merupakan mata kuliah wajib bagi mahasiswa mayor IKK.

Jumlah uang saku mahasiswa berkisar antara Rp200.000,00 hingga Rp4.500.000,00. Total uang saku per bulan mahasiswa dikelompokkan menjadi tiga kategori yaitu kurang dari sama dengan Rp600.000; antara Rp600.001,00 hingga Rp1.200.001,00; dan lebih dari Rp1.200.001,00. Sebagian besar uang saku mahasiswa $(70,0 \%)$ berada pada rentang Rp600.001,00 hingga Rp1.200.001,00 dengan rata-rata uang saku sebesar Rp917.040,00. Berdasarkan Indeks Prestasi Kumulatif (IPK), mahasiswa dalam penelitian memiliki IPK pada kisaran antara 1,99 hingga 3,90 . Proporsi terbesar IPK mahasiswa $(66,4 \%)$ berada pada rentang antara 2,76 sampai 3,50 .

Rata-rata usia ibu mahasiswa adalah 47,5 tahun, sedikit lebih muda dibandingkan dengan rata-rata usia ayah yakni 51,7 tahun. Proporsi terbesar usia ayah (48,9\%) berada pada rentang 51-60 tahun. Berbeda dengan ayah, lebih dari separuh usia ibu $(67,2 \%)$ berada pada rentang 41-50 tahun. Hasil menunjukkan bahwa hanya 1,2 persen usia ibu yang berada pada rentang 61-70 tahun. Usia termuda dari ayah dan ibu adalah 42 dan 38 tahun sedangkan usia tertua dari ayah dan ibu adalah 69 dan 65 tahun.

Berdasarkan lama pendidikan, proporsi terbesar lama pendidikan ayah $(35,1 \%)$ berada pada kategori 13-16 tahun sedangkan lama pendidikan ibu $(40,4 \%)$ berada pada kategori 10-12 tahun. Rata-rata lama pendidikan ayah dan ibu hanya berbeda kurang dari satu tahun yang mana rata-rata pendidikan ayah adalah 13,7 tahun sedangkan rata-rata lama pendidikan ibu adalah 12,9 tahun.

Jenis pekerjaan orang tua mahasiswa dikelompokkan secara umum menjadi petani, sopir, buruh, wiraswasta, Pegawai Negeri Sipil (PNS), pegawai swasta, dan pegawai BUMN. Lebih dari separuh ibu $(60,3 \%)$ merupakan ibu rumah tangga yang tidak bekerja. Selain itu, proporsi terbesar pekerjaan ayah (31,8\%) adalah sebagai PNS. Pendapatan keluarga mahasiswa berkisar antara Rp500.000,00 hingga Rp28.000.000,00 dengan pendapatan per kapitanya berada pada kisaran Rp93.750,00 hingga Rp6.666.667,00. Rata-rata pendapatan keluarga mahasiswa adalah sebesar Rp4.214.221,60 sedangkan rata-rata pendapatan per kapitanya sebesar Rp850.982,00. Lebih dari separuh pendapatan per kapita keluarga mahasiswa $(50,2 \%)$ berada pada kategori kurang dari sama dengan Rp680.000,00.

Besar keluarga dikategorikan berdasarkan NKKBS (Norma Keluarga Kecil Bahagia Sejahtera) yang dibedakan menjadi keluarga kecil dengan jumlah anggota kurang dari sama dengan 4 orang dan keluarga besar dengan jumlah anggota lebih dari 4 orang. Besar keluarga mahasiswa berkisar 2-13 orang sehingga keluarga mahasiswa sebagian besar $(71,2 \%)$ berada pada kategori keluarga besar.

Nilai diukur berdasarkan empat dimensi yaitu dimensi nilai keamanan, harga diri, pemenuhan diri, dan pencapaian prestasi. Keempat dimensi nilai ini dikelompokkan menjadi tiga kategori yaitu rendah, sedang, dan tinggi. Lebih dari separuh nilai keamanan $(58,8 \%)$ serta nilai harga diri $(65,2 \%)$ yang dimiliki responden berada pada kategori sedang dan sebagian besar nilai pemenuhan diri $(72,4 \%)$ serta nilai pencapaian prestasi $(71,2 \%)$ yang dimiliki responden berada pada kategori sedang.

\section{Pengetahuan Subjektif dan Objektif}

Pengukuran pengetahuan keuangan dilakukan dengan mengukur pengetahuan keuangan subjektif dan objektif. Hampir seluruh pengetahuan keuangan objektif mahasiswa $(90,8 \%)$ berada pada kategori tinggi, sisanya sebanyak 9,2 persen mahasiswa memiliki pengetahuan keuangan objektif yang berada pada kategori sedang. Tidak terdapat mahasiswa yang memiliki pengetahuan keuangan objektif yang berada pada kategori rendah. Selain itu, sebagian besar 

pengetahuan keuangan subjektif mahasiswa $(81,2 \%)$ berada pada kategori sedang, hanya 8,4 persen pengetahuan keuangan subjektif yang berada pada kategori tinggi.

\section{Komponen Pembentuk Niat.}

Sikap terhadap asuransi jiwa. Sikap terhadap asuransi jiwa dikelompokkan menjadi tiga kategori yaitu kategori rendah (skor 7-42), sedang (skor 43-77), dan tinggi (skor 78-112). Sebagian besar sikap mahasiswa terhadap asuransi jiwa (76,4\%) termasuk dalam kategori sedang. Hanya 4 persen sikap terhadap asuransi jiwa mahasiswa yang berada pada kategori tinggi, sisanya sebesar 19,6 persen berada pada kategori rendah. Skor terbesar sikap terhadap asuransi jiwa adalah 108 dan skor terkecilnya adalah 15 , sedangkan rata-rata skornya sebesar 54,8. Sebaran mahasiswa berdasarkan sikap terhadap asuransi jiwa disajikan pada Tabel 1.

Norma subjektif. Norma subjektif dibagi menjadi tiga kategori yaitu kategori rendah (skor 5-30), sedang (skor 31-55), dan tinggi (skor 56-80). Hanya 4 persen norma subjektif mahasiswa yang berada pada kategori tinggi. Lebih dari separuh norma subjektif mahasiswa $(52,0 \%)$ berada pada kategori sedang. Skor terbesar norma subjektif adalah 80 dan skor terkecilnya adalah 5, sedangkan rata-rata skornya adalah 34,2. Sebaran mahasiswa berdasarkan norma subjektif disajikan pada Tabel 1.

Kontrol perilaku yang dirasakan. Kontrol perilaku yang dirasakan dibagi menjadi tiga kategori yaitu kategori rendah (skor 5-30), sedang (skor 31-55), dan tinggi (skor 56-80). Skor terbesar kontrol perilaku yang dirasakan oleh mahasiswa dalam penelitian ini adalah 80 dan skor terkecilnya adalah 5 . Hampir 70 persen kontrol perilaku yang dirasakan oleh mahasiswa berada pada kategori sedang. Selain itu hanya 6,4 persen yang berada pada kategori tinggi. Rata-rata skor kontrol perilaku yang dirasakan oleh mahasiswa adalah 37,8. Sebaran mahasiswa berdasarkan kontrol perilaku yang dirasakan disajikan pada Tabel 1 .

Niat beli asuransi jiwa. Niat beli asuransi jiwa dalam penelitian dikategorikan menjadi dua bagian yaitu kategori tidak berniat yang dan kategori berniat. Sebagian besar mahasiswa $(81,6 \%)$ berniat membeli asuransi jiwa sedangkan sisanya sebanyak 18,4 persen tidak berniat membeli asuransi jiwa. Sebaran mahasiswa berdasarkan niat beli asuransi jiwa disajikan pada Tabel 1.
Tabel 1 Sebaran mahasiswa berdasarkan sikap, norma subjektif, kontrol perilaku yang dirasakan, dan niat beli asuransi jiwa

\begin{tabular}{|c|c|c|}
\hline Kategori & Jumlah & Persen \\
\hline \multicolumn{3}{|l|}{ Sikap } \\
\hline Rendah (skor 7-42 ) & 49 & 19,6 \\
\hline Sedang (skor 43-77) & 191 & 76,4 \\
\hline Tinggi (skor 78-112) & 10 & 4,0 \\
\hline Total & 250 & 100,0 \\
\hline Rata-rata $\pm S t a n d a r$ deviasi & \multicolumn{2}{|c|}{$54,8 \pm 14,2$} \\
\hline Rendah (skor 5-30) & 110 & 44,0 \\
\hline Sedang (skor 31-55) & 130 & 52,0 \\
\hline Tinggi (skor 56-80) & 10 & 4,0 \\
\hline Total & 250 & 100,0 \\
\hline Rata-rata $\pm S t a n d a r$ deviasi & \multicolumn{2}{|c|}{$34,2 \pm 13,4$} \\
\hline \multicolumn{3}{|l|}{ Kontrol perilaku } \\
\hline Rendah (skor 5-30) & 60 & 24,0 \\
\hline Sedang (skor 31-55) & 174 & 69,6 \\
\hline Tinggi (skor 56-80) & 16 & 6,4 \\
\hline Total & 250 & 100,0 \\
\hline Rata-rata \pm Standar deviasi & \multicolumn{2}{|c|}{$37,8 \pm 11,1$} \\
\hline \multicolumn{3}{|l|}{ Niat beli asuransi kesehatan } \\
\hline Tidak berniat (skor 1-2) & 26 & 10,4 \\
\hline Berniat (skor 3-4) & 224 & 89,6 \\
\hline Total & 250 & 100,0 \\
\hline \multicolumn{3}{|l|}{ Niat beli asuransi pendidikan } \\
\hline Tidak berniat (skor 1-2) & 31 & 12,4 \\
\hline Berniat (skor 3-4) & 219 & 87,6 \\
\hline Total & 250 & 100,0 \\
\hline \multicolumn{3}{|l|}{ Niat beli asuransi total } \\
\hline Tidak berniat (skor 1-2) & 46 & 18,4 \\
\hline Berniat (skor 3-4) & 204 & 81,6 \\
\hline Total & 250 & 100,0 \\
\hline
\end{tabular}

Hubungan antarvariabel Penelitian

Hubungan nilai dengan sikap terhadap asuransi jiwa, norma subjektif, dan kontrol perilaku yang dirasakan. Hasil uji korelasi Pearson menunjukkan adanya hubungan positif yang signifikan antara nilai keamanan dan sikap terhadap asuransi jiwa $(r=0,139, p<0,05)$. Artinya semakin tinggi nilai keamanan yang dimiliki mahasiswa maka semakin baik sikap mahasiswa terhadap asuransi jiwa. Nilai pemenuhan diri dengan sikap terhadap asuransi jiwa menunjukkan bahwa keduanya memiliki hubungan positif yang siginifikan dengan koefisien korelasi sebesar 0,164 $(p<0,01)$. Hal tersebut menunjukkan bahwa semakin tinggi nilai pemenuhan diri maka semakin baik sikap terhadap asuransi jiwa yang dimiliki mahasiswa. Selain itu, hasil penelitian juga menunjukkan bahwa nilai pencapaian prestasi memiliki hubungan positif signifikan dengan sikap terhadap asuransi jiwa $(r=0,153$, $p<0,05)$ sehingga semakin tinggi nilai 

pencapaian prestasi yang dimiliki maka semakin baik pula sikap terhadap asuransi jiwa.

Hasil lainnya menunjukkan bahwa terdapat hubungan positif yang signifikan antara keempat dimensi nilai dengan norma subjektif. Semakin tinggi nilai keamanan yang dimiliki mahasiswa maka semakin besar norma subjektif yang dirasakannya $(r=0,155, p<0,05)$. Semakin tinggi nilai harga diri yang dimiliki mahasiswa maka semakin besar norma subjektif yang dirasakannya $(r=0,158, p<0,05)$. Semakin tinggi nilai pemenuhan diri yang dimiliki mahasiswa maka semakin besar norma subjektif yang dirasakannya $(r=0,175, p<0,01)$. Lalu, semakin tinggi nilai pencapaian prestasi yang dimiliki mahasiswa maka semakin besar norma subjektif yang dirasakannya $(r=0,127$, $\mathrm{p}<0,01)$.

Keempat dimensi nilai juga memiliki hubungan positif yang signifikan dengan kontrol perilaku yang dirasakan. Berdasarkan uji korelasi Pearson yang telah dilakukan, diketahui bahwa semakin tinggi nilai keamanan yang dimiliki mahasiswa maka semakin besar kontrol perilaku yang dirasakannya $(r=0,258$, $\mathrm{p}<0,01)$. Semakin tinggi nilai harga diri yang dimiliki mahasiswa maka semakin besar kontrol perilaku yang dirasakannya $(r=0,236, p<0,01)$. Semakin tinggi nilai pemenuhan diri yang dimiliki mahasiswa maka semakin besar kontro perilaku yang dirasakannya $(r=0,262, p<0,01)$ dan semakin tinggi nilai pencapaian prestasi yang dimiliki mahasiswa maka semakin besar kontrol perilaku yang dirasakannya $(r=0,316$, $\mathrm{p}<0,01)$.

Hubungan pengetahuan keuangan dengan sikap terhadap asuransi jiwa, norma subjektif, dan kontrol perilaku yang dirasakan. Berdasarkan hasil analisis korelasi Pearson, diketahui bahwa terdapat hubungan positif yang signifikan antara pengetahuan subjektif dengan sikap terhadap asuransi jiwa $(r=0,345, p<0,01)$ serta pengetahuan objektif dengan sikap terhadap asuransi jiwa $(r=0,238$, $\mathrm{p}<0,01)$. Hasil ini menunjukkan bahwa semakin tinggi pengetahuan subjektif dan pengetahuan objektif mahasiswa maka sikap mahasiswa terhadap asuransi jiwa menjadi semakin baik.

Norma subjektif juga berhubungan signifikan positif dengan pengetahuan subjektif. Pengetahuan subjektif yang semakin baik dapat meningkatkan norma subjektif. Norma subjektif juga meningkat dengan bertambahnya pengetahuan objektif serta pengetahuan objektif dengan norma subjektif $(r=0,132$, $p<0,05)$ sehingga semakin tinggi pengetahuan subjektif dan pengetahuan objektif mahasiswa maka semakin besar norma subjektifnya. Selain itu, pengetahuan subjektif dan pengetahuan objektif pun memiliki hubungan positif yang signifikan dengan kontrol perilaku yang dirasakan, yang mana koefisien korelasinya masing-masing sebesar 0,492 $(p<0,01)$ dan $0,152(p<0,05)$. Artinya, semakin tinggi pengetahuan subjektif dan pengetahuan objektif mahasiswa maka semakin besar kontrol perilaku yang dirasakannya.

Hubungan Sikap terhadap Asuransi Jiwa, Norma Subjektif, dan Kontrol Perilaku yang Dirasakan dengan Niat Beli Asuransi Jiwa

Hasil uji korelasi Pearson menunjukkan bahwa terdapat hubungan positif yang signifikan antara sikap terhadap asuransi jiwa dan niat beli asuransi jiwa $(r=0,634, p<0,01)$. Hal tersebut menunjukkan bahwa semakin baik sikap terhadap asuransi jiwa maka semakin besar niat beli asuransi jiwa yang dimiliki mahasiswa. Norma subjektif pun menunjukkan hubungan positif yang signifikan dengan niat beli asuransi jiwa $(r=0,470, p<0,01)$. Artinya semakin besar norma subjektif yang dirasakan maka semakin besar niat beli asuransi jiwa yang dimiliki. Selain itu, hubungan positif yang signifikan pun ditunjukkan oleh kontrol perilaku yang dirasakan dan niat beli asuransi jiwa $(r=0,508, p<0,01)$ sehingga semakin besar kontrol perilaku yang dirasakan maka semakin besar niat beli asuransi jiwa yang dimiliki mahasiswa.

Faktor-Faktor yang Memengaruhi Niat Beli Asuransi Jiwa

Hasil uji regresi pada Tabel 2 menunjukkan bahwa faktor-faktor yang berpengaruh secara positif signifikan terhadap niat beli asuransi jiwa adalah nilai keamanan $(\beta=0,423, \quad p<0,05)$, pengetahuan keuangan subjektif $(\beta=0,200, p<0,1)$, dan sikap terhadap asuransi jiwa $(\beta=0,163, p<0,01)$. Sementara itu, nilai harga diri $(\beta=-0,169, p<0,1)$ berpengaruh secara negatif signifikan terhadap niat beli asuransi jiwa. Berdasarkan hasil tersebut maka dapat diketahui semakin tinggi dimensi nilai keamanan, pengetahuan keuangan subjektif dan sikap mahasiswa terhadap asuransi jiwa akan berpeluang memiliki niat lebih tinggi untuk membeli asuransi jiwa. Sedangkan peningkatan skor pada dimensi nilai harga diri berpeluang menurunkan niat beli asuransi jiwa pada mahasiswa. 

Tabel 2 Faktor yang berpengaruh terhadap niat beli asuransi jiwa

\begin{tabular}{|c|c|c|c|}
\hline \multirow[t]{2}{*}{ Variabel Bebas } & \multicolumn{3}{|c|}{$\begin{array}{c}\text { Niat beli asuransi jiwa } \\
\text { (1=berniat, } 0=\text { tidak berniat) }\end{array}$} \\
\hline & B & $\operatorname{Exp}(B)$ & Sig. \\
\hline Konstanta & $-10,767$ & 0,000 & $0,035^{\star *}$ \\
\hline $\begin{array}{l}\text { Jenis kelamin } \\
\text { (1=perempuan, } \\
0=\text { laki-laki) }\end{array}$ & 0,201 & 1,223 & 0,775 \\
\hline $\begin{array}{l}\text { Lama pendidikan } \\
\text { (bulan) }\end{array}$ & 0,044 & 1,045 & 0,436 \\
\hline Usia ayah (tahun) & $-0,020$ & 0,980 & 0,684 \\
\hline $\begin{array}{l}\text { Pendidikan ayah } \\
\text { (tahun) }\end{array}$ & $-0,120$ & 0,887 & 0,126 \\
\hline $\begin{array}{l}\text { Pendapatan per } \\
\text { kapita keluarga } \\
\text { (rupiah) }\end{array}$ & $-0,380$ & 0,684 & 0,330 \\
\hline $\begin{array}{l}\text { Nilai keamanan } \\
\text { (skor) }\end{array}$ & 0,423 & 1,526 & $0,014^{\star *}$ \\
\hline Nilai harga diri (skor) & $-0,169$ & 0,845 & $0,079^{*}$ \\
\hline $\begin{array}{l}\text { Pengetahuan } \\
\text { keuangan objektif } \\
(1=\text { benar, } 0=\text { salah) }\end{array}$ & 0,112 & 1,118 & 0,833 \\
\hline $\begin{array}{l}\text { Pengetahuan } \\
\text { keuangan subjektif } \\
\text { (skor) }\end{array}$ & 0,200 & 1,222 & $0,079^{*}$ \\
\hline $\begin{array}{l}\text { Sikap terhadap } \\
\text { asuransi jiwa (skor) }\end{array}$ & 0,163 & 1,178 & $0,000^{* * *}$ \\
\hline $\begin{array}{l}\text { Kontrol perilaku yang } \\
\text { dirasakan (skor) }\end{array}$ & 0,053 & 1,055 & 0,138 \\
\hline Negelkerke $R$ Square & & & 0,633 \\
\hline Sig & & & 0,000 \\
\hline
\end{tabular}

\section{PEMBAHASAN}

Nilai dan pengetahuan keuangan yang berbeda-beda diyakini akan menyebabkan perbedaan pada sikap terhadap asuransi jiwa, norma subjektif, dan kontrol perilaku yang dirasakan mahasiswa. Hasil penelitian yang dilakukan oleh Homer \& Kahle (1988) pun menunjukkan bahwa nilai yang dimiliki individu memiliki efek pada sikap konsumen. Hasil uji korelasi Pearson dalam penelitian ini menunjukkan adanya hubungan positif yang signifikan antara dimensi nilai keamanan, pemenuhan diri, dan pencapaian prestasi dengan sikap terhadap asuransi jiwa. Hal ini menunjukkan bahwa semakin tinggi nilai pada masing-masing dimensi tersebut maka semakin baik keyakinan dan evaluasi yang dimiliki mahasiswa terhadap manfaat asuransi jiwa. Menurut Dharmmesta (1998) sikap merupakan konsep yang mengekspresikan konsep diri dan sistem nilai sehingga fungsi sikap memungkinkan orang memperlihatkan nilai-nilai yang ada pada dirinya. Harga diri merupakan satusatunya dimensi nilai yang tidak memiliki hubungan yang signifikan dengan sikap terhadap asuransi jiwa. Hal ini dikarenakan seseorang dengan nilai harga diri yang tinggi nampak berani untuk mengambil risiko (Stone \& Allgaier, 2008).

Hasil penelitian menunjukkan bahwa keempat dimensi nilai MILOV dalam penelitian ini menunjukkan hubungan positif yang signifikan dengan norma subjektif dan kontrol perilaku yang dirasakan. Kamakura dan Novak (1992) dalam penelitiannya membagi nilai berdasarkan domain motivasi. Menurut Kamakura \& Novak (1992), dimensi nilai keamanan memiliki domain motivasi rasa aman, dimensi nilai harga diri dan pemenuhan diri memiliki domain motivasi yang mengarah pada diri sendiri sedangkan dimensi nilai pencapaian prestasi memiliki domain motivasi keberhasilan. Oleh karena itu, meningkatnya nilai keamanan untuk memperoleh rasa aman, meningkatnya nilai harga diri dan nilai pemenuhan diri demi kepentingan diri, serta meningkatnya nilai pencapaian prestasi demi meraih keberhasilan diyakini memiliki efek dalam membuat keputusan, mengetahui risiko, serta menentukan tujuan dan prioritas hidup pada diri mahasiswa sehingga hal tersebut diduga akan meningkatkan keyakinan normatif dalam norma subjektif dan keyakinan kontrol dalam kontrol perilaku yang dirasakan.

Berdasarkan hasil uji korelasi Pearson, terdapat hubungan positif yang signifikan antara kedua pengetahuan keuangan yang dimiliki mahasiswa (pengetahuan subjektif dan pengetahuan objektif) dengan sikap terhadap asuransi jiwa. Hasil penelitian menunjukkan bahwa semakin tinggi pengetahuan mahasiswa maka semakin positif sikapnya terhadap asuransi jiwa. Hal ini menunjukkan semakin banyak informasi yang dimiliki oleh mahasiswa maka semakin besar keyakinannya atas hasil yang akan diperoleh dari asuransi jiwa.

Hasil uji korelasi Pearson pun menunjukkan adanya hubungan positif yang signifikan antara pengetahuan keuangan subjektif serta objektif dengan norma subjektif. Semakin tinggi pengetahuan keuangan mahasiswa maka semakin besar norma subjektif yang dirasakannya. Hal ini menunjukkan bahwa pengetahuan keuangan yang semakin banyak akan memperkuat keyakinan mahasiswa terhadap pandangan orang-orang penting disekitarnya yang memotivasi mahasiswa agar membeli asuransi 

jiwa. Seperti halnya diungkapkan oleh Hershey dan Mowen (2000) bahwa pengetahuan memengaruhi persiapan atau perencanaan keuangan yang akan dilakukan.

Hasil lainnya menunjukkan bahwa pengetahuan keuangan subjektif dan objektif berhubungan positif signifikan dengan kontrol perilaku yang dirasakan. Chiou (1998) menyatakan bahwa pengetahuan subjektif dapat dianggap sebagai kepercayaan diri seseorang terhadap pengetahuan yang dimilikinya. Jika seseorang memiliki pengetahuan keuangan subjektif yang semakin tinggi maka orang tersebut akan memiliki kepercayaan diri yang lebih tinggi terhadap kemampuannya dalam melakukan sesuatu, di sisi lain seseorang yang pengetahuan keuangan subjektifnya lebih rendah maka kepercayaan dirinya untuk melakukan sesuatu pun semakin rendah. Oleh karena itu semakin banyak pengetahuan keuangan subjektif yang dimiliki oleh mahasiswa maka semakin besar keyakinannya untuk mengatasi hambatan dalam membeli asuransi jiwa. Selain itu, Chen dan Volpe (1998) melalui penelitiannya mengatakan bahwa seseorang dengan tingkat pengetahuan keuangan objektif yang lebih tinggi cenderung untuk memiliki pendapat dan keputusan yang benar terkait dengan perilaku keuangannya. Oleh karena itu, semakin tinggi pengetahuan keuangan objektif yang dimiliki oleh mahasiswa maka semakin besar keyakinannya untuk mengatasi hambatan dalam membeli asuransi jiwa karena mahasiswa tersebut memiliki pendapat dan keputusan keuangan yang lebih baik.

Ajzen (1991) mengatakan bahwa semakin baik sikap terhadap perilaku, semakin besar norma subjektif yang dirasakan, serta semakin besar kontrol perilaku yang dirasakan maka seharusnya semakin besar niat seseorang untuk melakukan suatu perilaku. Hasil penelitian ini menunjukkan hal yang senada yakni sikap terhadap asuransi jiwa, norma subjektif, dan kontrol perilaku yang dirasakan memiliki hubungan positif yang signifikan dengan niat beli asuransi jiwa. Artinya, semakin baik sikap terhadap asuransi jiwa, semakin besar norma subjektif yang dirasakan, serta semakin besar kontrol perilaku yang dirasakan maka semakin besar niat mahasiswa untuk membeli asuransi jiwa.

Hasil penelitian menunjukkan bahwa terdapat beberapa faktor yang berpengaruh signifikan terhadap niat beli asuransi jiwa. Faktor-faktor tersebut diantaranya adalah dimensi nilai keamanan, dimensi nilai harga diri, pengetahuan subjektif, dan sikap terhadap asuransi jiwa. Dimensi nilai keamanan memiliki pengaruh positif yang signifikan terhadap niat beli asuransi jiwa sedangkan dimensi nilai harga diri memiliki pengaruh negatif yang signifikan terhadap niat beli asuransi jiwa. Hasil penelitian ini sejalan dengan Astuti dan Hartoyo (2013) dalam hasil penelitiannya yang menunjukkan bahwa mahasiswa cenderung memiliki orientasi yang rendah pada nilai harga diri dan percaya bahwa keamanan diri merupakan hal yang penting. Menurut Stone dan Allgaier (2008) terdapat nilai-nilai yang berkaitan dengan perilaku pengambilan risiko, baik secara negatif maupun positif. Nilai yang memiliki motivasi rasa aman (seperti nilai keamanan) akan menghindari risiko sedangkan nilai yang memiliki motivasi terarah pada diri sendiri (seperti nilai harga diri) nampak berani mengambil risiko. Oleh karena itu semakin tinggi nilai keamanan yang dimiliki maka peluang mahasiswa untuk berniat membeli asuransi jiwa semakin besar. Hal ini dikarenakan nilai keamanan yang semakin tinggi akan mengarahkan mahasiswa untuk menghindari risiko dengan berniat membeli asuransi jiwa. Sedangkan semakin tinggi nilai harga diri yang dimiliki maka peluang mahasiswa untuk berniat membeli asuransi jiwa akan semakin kecil. Hal ini dikarenakan nilai harga diri yang semakin tinggi mengarahkan mahasiswa dalam mengambil risiko dengan tidak berniat membeli asuransi jiwa.

Pengetahuan keuangan subjektif mahasiswa memiliki pengaruh positif yang signifikan terhadap niat beli asuransi jiwa. Hal ini menunjukkan bahwa persepsi mahasiswa mengenai banyaknya pengetahuan yang dimilikinya berpengaruh terhadap keinginan untuk membeli asuransi jiwa. Niat merupakan kemungkinan subjektif individu untuk berperilaku tertentu (Fishbein \& Ajzen, 1975), yang mana kemungkinan tersebut dibangun dari tingkat keyakinan individu. Seperti yang telah dikemukakan oleh Chiou (1998), pengetahuan subjektif merupakan wujud dari kepercayaan diri seseorang terhadap kemampuannya untuk melakukan sesuatu. Pengetahuan subjektif dalam penelitian ini menunjukkan hubungan yang erat dengan keyakinan mahasiswa dalam melakukan niat pembelian, yang mana semakin baik persepsi mahasiswa mengenai pengetahuan yang ia miliki maka semakin besar keyakinannya untuk dapat melakukan niat pembelian asuransi jiwa. Oleh karena itu, mahasiswa yang memiliki pengetahuan subjektif yang baik akan memiliki keyakinan yang besar untuk melakukan pembelian asuransi jiwa sehingga peluangnya 

untuk memiliki niat beli asuransi jiwa akan semakin besar.

Fishbein \& Ajzen (1975) menyatakan bahwa niat seringkali dilihat sebagai komponen konatif dari sikap. Hasil uji pengaruh menunjukkan bahwa sikap terhadap asuransi jiwa berpengaruh positif signifikan terhadap niat beli asuransi jiwa. Mahasiswa dengan sikap terhadap asuransi jiwa yang lebih baik, berpeluang lebih besar untuk memiliki niat beli asuransi jiwa. Hal ini dikarenakan jika seseorang menyukai objek tertentu maka ia memegang keyakinan yang baik mengenai objek tersebut dan tentunya memiliki niat untuk melakukan perilaku yang berkaitan dengan objek yang disukainya (Fishbein \& Ajzen, 1975).

\section{SIMPULAN DAN SARAN}

Hasil penelitian menunjukkan bahwa persentase terbanyak dari nilai keamanan, harga diri, pemenuhan diri, dan pencapaian prestasi yang dimiliki oleh mahasiswa berada pada kategori sedang. Pengetahuan keuangan yang dimiliki oleh mahasiswa terbilang cukup baik, hal ini terlihat dari pengetahuan keuangan subjektif mahasiswa yang sebagian besar berada pada kategori sedang dan pengetahuan keuangan objektif mahasiswa yang hampir seluruhnya berada pada kategori tinggi. Walaupun proporsi terbesar sikap terhadap asuransi jiwa, norma subjektif, dan kontrol perilaku yang dirasakan oleh mahasiswa berada pada kategori sedang namun hasil penelitian menunjukkan bahwa sebagian besar mahasiswa memiliki niat beli asuransi jiwa

Terdapat hubungan positif yang signifikan antara nilai dan pengetahuan keuangan dengan tiga komponen utama pembentuk niat dalam Theory of Planned behavior (sikap terhadap asuransi jiwa, norma subjektif, dan kontrol perilaku yang dirasakan). Hanya dimensi nilai harga diri yang tidak menunjukkan hubungan yang signifikan dengan sikap terhadap asuransi jiwa. Sesuai dengan dengan pernyataan Theory of Planned behavior, semakin baik sikap terhadap asuransi jiwa, semakin besar norma subjektif, dan semakin besar kontrol perilaku yang dirasakan oleh mahasiswa maka semakin besar pula niat beli asuransi jiwa yang dimiliki mahasiswa.

Uji pengaruh menunjukkan terdapat beberapa faktor yang berpengaruh signifikan terhadap niat beli asuransi jiwa. Dimensi nilai keamanan, pengetahuan keuangan subjektif, dan sikap terhadap asuransi jiwa berpengaruh positif signifikan dengan niat beli asuransi jiwa sedangkan dimensi nilai harga diri berpengaruh negatif signifikan terhadap niat beli asuransi jiwa. Artinya, semakin tinggi nilai keamanan, semakin tinggi pengetahuan keuangan subjektif, dan semakin tinggi sikap terhadap asuransi jiwa yang dimiliki mahasiswa maka peluangnya untuk berniat membeli asuransi jiwa akan semakin besar. Sebaliknya, semakin tinggi nilai harga diri yang dimiliki mahasiswa maka peluangnnya untuk berniat membeli asuransi jiwa semakin kecil.

Sebagian besar pengetahuan keuangan subjektif dan sikap terhadap asuransi jiwa yang dimiliki mahasiswa masih tergolong sedang, hanya sebagian kecil mahasiswa yang memiliki pengetahuan keuangan subjektif dan sikap terhadap asuransi jiwa yang tergolong tinggi. Seperti yang dapat diketahui dari hasil penelitian, pengetahuan keuangan subjektif dan sikap terhadap asuransi jiwa memiliki peran dalam meningkatkan niat beli asuransi jiwa. Oleh karena itu untuk meningkatkan niat beli asuransi jiwa maka pengetahuan keuangan subjektif mahasiswa dan sikap terhadap asuransi jiwa sudah seharusnya lebih ditingkatkan lagi. Pengetahuan keuangan subjektif dan sikap terhadap asurannsi jiwa dapat ditingkatkan dengan mengikuti seminar mengenai asuransi jiwa dan jugadengan membaca berita atau menonton tayangan terkait asuransi jiwa yang dapat menyentuh aspek afektif (emosi dan perasaan) sehingga persepsi dan keyakinan yang dimiliki oleh mahasiswa mengenai asuransi jiwa akan menjadi lebih baik.

Bagi penelitian selanjutnya, disarankan untuk melihat niat beli asuransi jiwa menggunakan Theory of Planned Behavior pada kelompok responden yang lebih luas, misalnya pada orang-orang yang telah memiliki tanggungan keluarga sehingga dapat diketahui apakah terdapat faktor-faktor lain yang berpengaruh terhadap niat beli asuransi jiwa.

\section{DAFTAR PUSTAKA}

Astuti, R. N., \& Hartoyo. (2013). Pengaruh nilai, tingkat pengetahuan, dan sikap terhadap perencanaan keuangan hari tua. Jur. IIm. Kel. \& Kons., 6(2), 109-118.

Ajzen, I. (1991). The theory of planned behavior. Organizational Behavior and Human Decision Processes, 50(2), 179211. 

[Bapepam-LK] Badan Pengawas Pasar Modal dan Lembaga Keuangan. (2009). Perasuransian Indonesia. Jakarta, ID: Bapepam-LK.

Chen, H., \& Volpe, R. P. (1998). An Analysis of Personal Financial Literacy Among College Students. Financial Service Review, 7(2), 107-128.

Chiou, J. S. (1998). The effects of attitude, subjective norm, and perceived behavioral control on consumers' purchase intentions: the moderating effects of product knowledge and attention to social comparison information. Proc. Natl. Sci. Counc. ROC (C), 9(2), 293-308.

Dharmmesta, B. S. (1998). Theory of planned behavior dalam penelitian sikap, niat dan perilaku konsumen. Kelola, 8(7), 85-103.

Fishbein, M., \& Ajzen, I. (1975). Belief, attitude, intention, and behavior an introduction to theory and research. Wesley: MA Addison.
Hallman, G.V, \& Rosenbloom, J.S. (2003). Personal financial planning. $7^{\text {th }}$ ed. New York, US: McGraw-Hill.

Hershey, D. A., \& Mowen, J.C. (2000). Pscychological determinants of financial preparedness for retirement. Gorontologist, 40, 687-697.

Homer, P. M., \& Kahle L.R. (1988). A structural equation test of the value-attitude-behavior hierarchy [Abstrack]. Journal of Personality and Social Psychology, 54(4), 638-646.

Kamakura, W. A., Novak, T. P. (1992). Valuesystem segmentation: Exploring the meaning of lov. Journal of Consumer Research, 19(1), 119-132.

Stone, E. R, \& Allgaier, L. (2008). A social values analysis of self-other differences in decision making involving risk. Basic And Applied Social Psychology, 30, 114-129. 